\title{
Organizational Trust and Workplace Deviant Behaviour in Higher Institutions in Rivers State
}

\author{
Dr Omoankhanlen Joseph Akhigbe ${ }^{1}$, Philip Imefon Sunday ${ }^{1}$ \\ ${ }^{I}$ Department of Management, Faculty of Management Sciences, University of Port Harcourt \\ *Corresponding Author: Dr Omoankhanlen Joseph Akhigbe, Department of Management, Faculty of \\ Management Sciences, University of Port Harcourt
}

\begin{abstract}
This research work examined the relationship between organizational trust and workplace deviantbehaviour among employees of higher institutions in Rivers state. The study adopted a cross-sectional survey which is a type of quasi experimental research design. A well-structured questionnaire designed by the researcher which covered the study dimensions and measures was used for data generation and the study made use of simple random sampling technique with a sample size of 122 drawn from a population of 175 respondents from six higher institutions in Rivers state. The Spearman rank-order correlation coefficient was used in testing the research hypotheses. The results of the findings revealed that organizational trust has a significant relationship with workplace deviant-behaviour. Therefore, it was recommended that Management should encourage team work among employees to boost their level of interpersonal trust. Incentives should be given to hard working staff as this will motivate others to work hard towards achieving success other than causing harm to the organization.
\end{abstract}

Keywords: Organizational Trust, workplace deviant behaviour.

\section{INTRODUCTION}

The workplace is an environment made up of so many people coming from different background. As such, different behaviour is displayed by these people in the work place. However, each of this behaviour affects another person within the organization as well as the entire organization. These behaviours can either fall within or outside the organizational norms and principles. Hence, those voluntary behaviours by employees that violates significant organizational norms, principles, policies or rules and regulation of the organization is referred to as workplace deviant behaviour (Robinson \& Bennett, 1995) in Matthew, Chigozie\&Kosiso (2014).

The term "deviant behaviour" has been given so many names by different researchers. Some call it counterproductive behaviour, others call it anti-social behaviour and it is prevalent in virtually every organization. It could either be positive or negative (Appelbaum, Iaconi\&Matousek, 2007) in Muafi (2011). Galperin (2002) view positive deviant behaviour as voluntary behaviour that is contrary to the laid down principles and essential norms of an organization but contributes to the well-being of an organization, its members or both. Example of positive work place deviant behaviour include noncompliance with dysfunctional directives, criticizing incompetent superiors, disobeying managerial orders in order to improve organizational processes, exhibiting behaviours that challenge existing norms in order to help the organization have an edge over its competitors or increase its profitability (Spreitzer\&Sonenshein, 2004) in Muafi (2011). On the other hand, negative deviant behaviour are those voluntary behaviours put on by an employee to either harm other workers in the organization or cause havoc to the entire organization (Robinson \& Bennett, 1995). Such behaviour includes absenteeism, lateness to work, bribery, theft, wasting the organization's resources, sexual harassment (Appelbaum, Iaconi\&Matousek, 2007) in Muafi (2011).

For the purpose of this work, the emphasis will be on the negative deviant behaviours because negative deviant behaviour has restrained individual employee's performance thereby affecting the total output of the organization (Muafi, 2011).

The work environments in Nigeria are characterized by negative deviant behaviours that hinder the growth and development of any society (Mathew, Chigozie \& Kosiso, 2014). Research made by 
Merrell, Ervin and Gimpel-Peacock (2012) showed that individual's anti-social behaviour are shaped by the influence of their co-workers as they found significant relationship between the level of antisocial behaviour exhibited by newly inducted employees and that which was exhibited by their coworkers. For instance, newly inducted employees come and meet the old ones stealing company's property, they might be influenced by the old ones to follow suit.

However, managing the negative deviant behaviour in an organization is expensive. A study carried out by Omar, Halim, Zainab, Farhadi, Nasir and Khairudin (2011) shows that billions of dollars have been wasted on workplace deviant behaviour nationwide and that deviant behaviouris that of exorbitant cost when it is directed toward the organization. Therefore, organizations are to ensure that they try as much as they could to see that employees expectation are met as this may curtail or eradicate the rate at which employees deviate from the standard rules, regulations and norms of the organization. Failure to do that, may lead to mistrust thus, affecting the goal of the organization. Research made by Sunday (2013) suggested that Human Resource managers need to build a trusting environment as this will enable group members show high positive reactions to their organization and perform their jobs better with little or no supervision. Joe-Akunne, Oguegbe and Okonkwo (2015) sees Job boredom to be a potent predictor of workplace deviant behaviour and therefore urges institutions, organizations and government to create an atmosphere that will be conducive for workers thereby stabilizing their mental ability and reducing workplace deviant behaviour.

Deviant behaviour is seen to be a reaction to frustrating organizational stressors such as financial, social and working conditions (Robinson \& Bennett, 1997). It is an increasing problem leading to a huge financial loss (Greenberg 1997; Murphy 1993; Vardi\&Wiener (1996). Employees who are target of workplace deviance are more likely to quit, have stress-related problems decreased productivity, low morale and lost work time (O’Leary-Kelly, Griffin \&Glew 1996).

There has been series of research on workplace deviant behaviour in this 21 st century. Rafiee, Hoveida and Rajaeipoor (2015) researched on the relationship between deviant work place behaviour, organizational justice and staff development in the universities of Tehran. Anwar, Sarwar, Awan and Arif (2011) investigated gender differences in workplace deviant behaviour. Matthew, Chigozie and Kosiso (2014) researched on Workplace Deviance: A predictive study of occupational stress and Emotional Intelligence among Secondary school Teachers. Chikwature\&Oyedele (2016) investigated the effects of deviant behaviour on Academic performance in Mature Urban primary schools in Mature District.

Similarly, research on Organizational trust has received a lot of attention since the mid 1990's till date. Organizational trust is defined as the ability of individuals to internalize the viewpoint of the system, in order to protect every member of the organization and also recognize their contribution to achieving organization's goals McDonough (1985) in Rusu \& Babos 2015). Organizational trust does not only involve a worker trusting another worker (interpersonal trust), it also involves situation and structures (impersonal trust). Impersonal trust is the employees feeling of confidence that favourable conditions are in place that are conducive to situational success in a risky environment (Hassan and Semerciöz, 2010). Trust is an essential ingredient in every organization which can avert a lot of things from collapsing and absence of it in an organization could be catastrophic (Panahi, 2008). For instance, employees trust for the organization could increase output and general performance of the organization but absence of employee trust for the organization they work in could prompt employees to put up deviant behaviour such as stealing from co- workers and the company and this, could lead to organizational inefficiency (Colquitt, Scott \&Lepine, 2007).

Many researchers have carried out research on organizational trust. Few to mention are Rezaei, Salehi, Shafiei and Sabet (2012) who researched on Servant leadership and Organizational Trust. Nwankpa and Roumani (2014) researched on the influence of organizational Trust and organizational mindfulness on Enterprise Resource Planning (ERP) systems usage. Dursun (2015) investigated the relationship between Organizational Trust, Organizational Support and Organizational Commitment.

Although numerous researches have been carried out on the two variables (organizational trust 'and work place deviant behaviour) used in this study both together and with other variables, other prior researches have not investigated the relationship between organizational trust and workplace deviant behaviour among employees of higher institutions. Therefore, this research aims at adding to existing body of literature on organizational trust and workplace deviant behaviour by examining the 
relationship between organizational trust and work place deviant behaviour among employees of higher institutions in Rivers state.

\section{Statement of the Problem}

O'Leary-Kelly, Griffin and Glew (1996) research revealed that employees who are target of work place deviant behaviour are more likely to quit, have stress related problem, decreased productivity, low morale and lost work time.

Impersonal trust used as a dimension of organizational trust in this study refers to employees trust in top management that the institution will not fail because of the reliable structure, processes and technology put in place for effective functioning of the organization, impersonal trust otherwise known as institutional trust is employee's trust for the system other than specific individual (Hassan \&Semerciöz, 2010). Once this trust is breached, that is, when the organization's structures that motivated employees are no longer in place, employees are likely to work below average thereby reducing the general performance of the organization. Lack of employee trust for the organization they work in, could even lead to employee's display of deviant behaviours such as theft, sabotaging equipment and what have you, in the work place (Rusu\&Babos, 2015).

Interpersonal trust on the other hand is the trust that exists among co-workers and between workers and their supervisors. If a worker trusts in a co-worker but at the end of the day their trust for each other is betrayed, it could lead to breakdown in communication (malice), sometimes it may result into verbal abuse in the work place and this in turn affects the organization's output as there will be no cooperation between these two people when working (Geller, 1999) in Bakiev (2013). Organizational deviance and interpersonal deviance are the two measures of workplace deviant behaviour used in this study. Organizational deviance is deviance directed towards the organization while interpersonal deviance is deviance directed towards a fellow worker (Robinson \&Bennet, 1997). The negative deviance is what no organization wishes to see in their employees because deviance whether targeted towards the organization or a co- worker is expensive as it leads to enormous financial loss or spending by the organization which can further reduce profit or even deteriorate the working capital (Muafi, 2011).

Therefore, this research aims at examining the relationship between organizational trust and workplace deviant behaviour among employees of selected higher institutions in Rivers state thus, what will be the challenges higher institutions in Rivers state will be faced with if this study on organizational trust and work place deviant behaviour is ignored? That is the study problem and the researcher would not want such consequences to surface.

\section{THE OPERATIONAL FRAMEWORK OF THE STUDY}

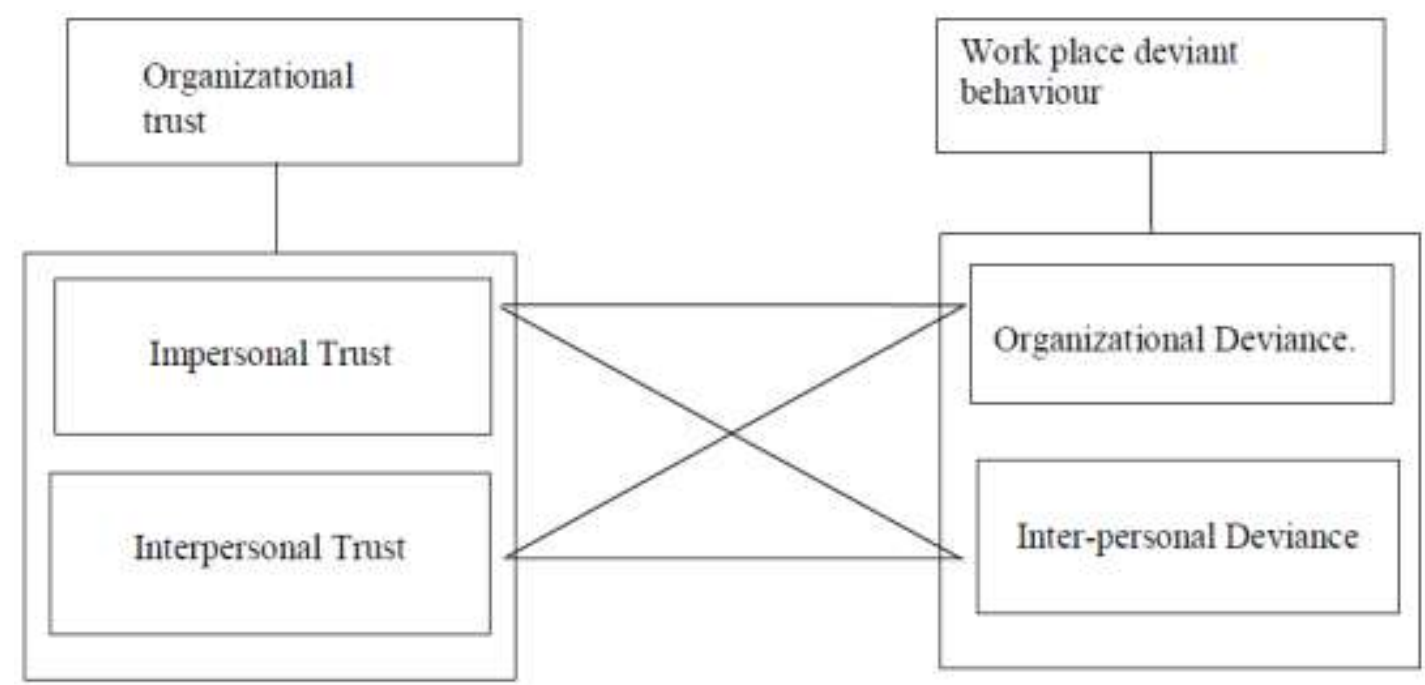

Source: Operationalized by the researcher, 2017.

The diagram above shows the relationship between organizational trust and workplace deviant behaviour. Robinson and Bennett $(1995,1997)$ identified a typology of workplace deviance. They opined that the distinction between types of deviance was whether the deviance was directed at the 
organization (organizational deviance) or at members of the organization (interpersonal deviance). Therefore, this study will look extensively at organizational deviance and interpersonal deviance as measures of workplace deviant behaviour.

Similarly, previous research made by Atkinson and Butcher (2003) pointed out that the key dimensions that captures organizational trust include: impersonal trust (institutional trust) and Interpersonal trust. Therefore, this study will make use of impersonal trust and interpersonal trust as dimensions of organizational trust.

\section{AIM AND OBJECTIVES OF THE STUDY}

The general aim of this study is to examine the relationship between organizational trust and workplace deviant behaviour. The specific objectives of the study are:

a) To examine the relationship between impersonal trust and organizational deviance in Selected higher institutions in Rivers State - Nigeria

b) To examine the relationship between impersonal trust and interpersonal deviance in Selected higher institutions in Rivers State - Nigeria

c) To examine the relationship between interpersonal trust and organizational deviance in Selected higher institutions in Rivers State - Nigeria

d) To examine the relationship between interpersonal trust and interpersonal deviance in Selected higher institutions in Rivers State - Nigeria

\section{RESEARCH HYPOTHESES}

The following null hypotheses were generated for the study.

$\mathbf{H O}_{1}$ : There is no significant relationship between impersonal trust and organizational deviance in selected higher institutions in Rivers state

$\mathbf{H O}_{2}$ : There is no significant relationship between impersonal trust and interpersonal deviance in selected higher institutions in Rivers state

HO$_{3}$ : There is no significant relationship between interpersonal trust and organizational deviance in selected higher institutions in Rivers state

$\mathbf{H O}_{4}$ : There is no significant relationship between interpersonal trust and interpersonal deviance in selected higher institutions in Rivers state

\section{LiTERATURE REVIEW}

\subsection{Concept of Organizational Trust}

Organizational trust is defined as a universal moral rule in a corporate organization which people display behaviours mutually towards each other (Morgan \& Haunt, 1994). Organizational trust is defined as confidence in the outcome of a situation. It is an expectation about the positive actions of other people without the ability to control the outcome directly (O'Brein, 2001). Organizational trust is also defined as a feeling of confidence in an employer and the belief that the employer will be supportive by being honest, following through with commitment (Gilbert and Tang, 1998). Organizational trust can be established when the top management actions could be predicted and when leaders are consistent in their words and actions (Reina \& Reina, 1999). Organizational trust according to Shaw (1997) is defined as people's belief to attain their goals and expectations which are dependent on other people. Organizational trust is also defined as a process which entails attributes such as faith, truth, diligence and honesty which are formed during interaction with people working within an organization; these attributes grows over time to become part of the organization and could be used to achieve a specific purpose (Arslan, 2009) as cited in Yeliz (2016). Organizational trust is also defined as an atmosphere where people emotionally feel safe and secure as they interact and accept each other (Celik, Turunç\&Begenirbas, 2011). With regards to Mishra's (1996) model of organizational trust cited in Nwankpa (2014), organizational trust is defined as the concrete assurance which individual employee have about their organization; that having played their own part, obeying all the rules and regulations and effectively carrying out their duties, the organization will not fail to meet their expectation. It is also believed that organizational trust is the acceptance of one person in an organization being ready to bear the actions of another person based on the expectation that the other will perform an action of mutual interest (Meyer, Davis \&Schoorman, 1995).Organizational 
trust is defined as an atmosphere where people emotionally feel safe and secure as they interact and accept each other Gibbs (1972) in Aslani, Soraya and Zavari (2014). Organizational trust is a bilateral process between managers, leaders and employees of the organization (Demircan \& Ceylan, 2003) in (Gülsüm, Adem, Mehmet, Liker \& Mehdi, 2016). Organizational trust is also seen to be the trust members of an organization have about the organization's vision and strategy, as well as the technological and commercial aspect of the organization (Hassan \&Semerciöz, 2010). Competence, its fair processes and structures, as well as the human resources policies were included by Ellonen, Blomqvist \& Puumalainen (2008) in addition to what Hassan \&Semerciöz (2010) earlier mentioned .Organizational trust is seen to be a concept which brings about a healthy communication relationship and coherency in the workplace which eventually leads to success; as such, trust should be treasured, preserved and nurtured after establishing it because trust once lost, is difficult to be restored (Esptein \& Currall, 2003). Trust is not a coincident or mirage which just occur, it is established through individual and collective learning processes; when active members come together and interact among themselves with the aim of fulfilling mutual expectations, the result of such interaction brings about organizational trust (Lazaric,2003) in Erat, ErdiII, Kitapçi and Çömlek (2012).

Based on the several definitions of Organizational trust, it could be concluded that for there to be trust in an organization, two parties must be involved. Trust whether personal or professionally is a psychological notion which has the ability to control the behaviour and intentions of an individual (Webster \& Wong, 2008) cited in Samadi, Chin and Seyfee (2015).

Organizational trust could however be analyzed in three levels. Trust in colleagues (interpersonal trust), subordinate trust in leader or supervisor and trust in organization or institution (organizational trust).

\subsection{Interpersonal Trust}

Inter-personal trust is the trust an individual employee has for a co-worker (Geller 1999) as cited in Bakiev (2013). For employees to be effective, efficient and perform their job successfully, which hitherto leads to the overall success of the organization, there has to be a high level of trust among employees in the organization (Bakiev, 2013). When employees lack trust for each other in the workplace, their performance level tends to be low (Bilgic, 2011). Trust among employees of workplace is an essential ingredient because the presence of it increases productivity and quality (O'Brein, 2001). When employee feels good and have mutual trust among them in the workplace, they tend to work harder, accepting more responsibility and challenges (Reina \& Reina, 1999).

\subsection{Subordinate Trust in Leader}

Subordinate trust in leader refers to employees trust in their leader's integrity, competence, and openness (Liden, 2005). A competent leader is one who is consistent in his word and bahaviour or actions (Reina \& Reina, 1999). A leader can only lead others well if he/she has attributes such as integrity, allow participation, delegate responsibilities with the confident that the trustee will execute appropriately as required of him or her, establishing an effective communication system with employees and considering what is best (Omarov, 2009). Leaders who have these attribute can also inspire trust on others (Liden, 2005). Subordinate trust in leaders is likely to be affected by both in organizational perspective since the leader represent the organization and inter-personal perspective since the leader interact with other leaders and with subordinates. (Shamir \&Lapidot, 2003).

\subsection{Concept of Workplace Deviant Behaviour}

Workplace deviant behaviour is defined as a deliberate behaviour carried out by employee which breach the significant norms of the organization and in so doing threatens the well being of the organization (Robinson and Bennett, 1995) in (Kabiru, Faridahwati and Ajay 2013). A study by Spector and Fox (2002) in Mathew, Chigozie and Kosiso (2014) defined workplace deviant behaviour as any act which violates the basic rules or organizational life. Deviant behaviour is the purposeful action of employees that contradict with the pre-determined goals of the organization and also threatens the well being of the organization, its members or both (Chang \&Smithikrai, 2012). A behaviour is deemed deviant when organization's customs, policies or internal rules and regulations are violated by an individual or a group thereby causing havoc to members of the organization or the entire organization (Bennet\& Robinson, 2003). Work place deviant behaviour is the intentional act executed by employee which at times could result in causing harm to the organization (Omar,Halim, Zainah, Farhadi, Nasir\&Kairudi, 2011). Work place deviant behaviour is also defined by Warren (2003) as departure from important norms and standards of the organization. 
However, there are two types of workplace deviant behaviour and they include constructive or positive workplace deviant behaviour and destructive or negative workplace deviant behaviour (Bennet and Stamper, 2001) in Yildiz, Alpkan, Ateș and Sezen (2015).

\subsection{Constructive or Positive Deviant}

Constructive or positive deviant behaviour is the purposeful exhibition of behaviours by employee which goes outside the significant norms and rules of the organization with the aim of contributing to the betterment of the organization, its members or both (Galperin, 2002). Constructive deviant behaviour is viewed by Spreitzer and Sonenshein (2003) to be behaviours that are against the standard of a particular group but in a respectful manner. While Vadera, Pratt and Mishra (2013) defined constructive deviant behaviour as behaviours that conflict with the significant norms of a particular group but beneficial to the group by helping the group achieve its goals. Such behaviour brings innovation and change to the organization (Galperin, 2012). Constructive deviant behaviour is categorized into inter-personal constructive deviance and organizational constructive deviance (Galperin\& Burke, 2006). The author defined inter-personal constructive deviance as those behaviour directed toward individuals and which comprises of behaviours such as disobeying managerial orders and reporting a co- worker who does something wrong. Organizational constructive deviance on the other hand is directed at organization. Example of behaviour directed at the organization are behaviours that breach significant norms of the organization with the aim of achieving success and displaying behaviours that are innovative and creative which could be useful for carrying out daily activities and overcoming difficulties encountered during operations in the organization as well as solving the problems of customers (Galperin\& Burke, 2006).

\subsection{Destructive or Negative Deviant Behaviour}

Destructive or negative deviant behaviours are those behaviours that violate the significant norms and principles of a group or organization, hence, causing harm to the organization its members or both (Mathew, Chigozie\&Kosisi, 2014). The negative or destructive deviant behaviour is dangerous and will always bring a setback especially in the aspect of organizational performance ( Appelbaum, Iaconi\&Matousek, 2007). Behaviours are said to be destructive when they are not beneficial to the organization, its members or both for instance, behaviours that aims at satisfying one selfish interest instead of that of the organization or its members are referred to as destructive deviant behaviour (Warren, 2003). However, behaviours that violate the norms of the organization discourage various cooperative and team oriented behaviours that the organization would prefer. Examples of such behaviours are abseentism, theft, sexual harassment (Greenberg, 1997).

\subsection{Dimensions of Organizational Trust}

A study carried out by Atkinson and Butcher (2003) pointed out that organizational trust is a multidimensional foci; that an employee may trust his co-worker but does not trust his supervisor or top management and therefore, they opined that organizations will have to rely on both impersonal and interpersonal type of trust as the two, complement each other. Therefore, this study will make use of impersonal trust and interpersonal trust as organizational trust dimensions.

\subsection{Impersonal Trust}

Impersonal trust is otherwise known as institutional trust. Impersonal trust refers to top management ability to develop relationship with employee beyond those whom they interact frequently; top management are the people who are seen at the peak of the organizational chart, controlling the organization and making important decision (Semerciöz, Hassan \&Aldemir, 2011). Impersonal trust entails structuring the organization in such a way that the culture and processes that governs the organization are of standard and will be able to stand the test of time thereby giving hope to employees in the organization that their job is protected (Semerciöz, Hassan \&Aldemir, 2011). Impersonal trust is defined as the belief by employees that adequate institutional structures are in place to enable the employee anticipates a successful future (McKnight, Cummings \&Chervany, 2008). Such institutional structure includes conducive environment, competent staff, standard norms and regulations that can guarantee success. It is the trust in the system other than specific individuals (Hassan \&Semerciöz, 2010). An illustration of what impersonal trust is, was given by Sztompka (1999) when he said if he decides to fly with Lufthansa airline from Tokyo, it means that he trust the company's pilot and other members of the crew, the technicians, inspectors, supervisors and so on. He added that there is no need to personally know all of them before using their plane; thus, this is trust in the company's structure. If employees distrust the structure and processes of the institution they work 
in, they will not carry out their contractual duties. This implies that if an organization or institution uses inferior technology, employ incompetent people as top managers, then employees confident is bound to waver (Dasguspa, 1988).

\subsection{Interpersonal Trust}

Interpersonal trust is defined as the degree to which people ascribe good intentions and abilities to their peers in the workplace (Geller,1999) in Bakiev (2013). Interpersonal trust is defined as the trust relations that exist among equals who share a similar work situation McCauley \&Kuhnert (1992). Interpersonal trust is an employee's acceptance to be vulnerable to a co-worker based on the belief that the co-worker is competent, open, concerned and reliable (Mishra, 1996). Interpersonal trust according to McAllister (2005) is the degree to which a worker has a positive feeling in another worker and willing to act based on the trustee's word, action and decision. He further divided interpersonal trust into cognitive based interpersonal trust and affective-based interpersonal trust.

Cognitive based trust is the trust a person has for another based on the trustee's abilities, competencies, reliabilities, work experiences and quality of work (Zhu, Newman, Miao \&Hooke, 2013). Cognitive based trust is describe as a situation whereby an employee trust his fellow worker based on the fellow worker's past record (Johnson \& Grayson, 2005). However, cognitive based trust is seen to be a force which encourages professional association among workers of the same organization (Chowdhury, 2005).

Affective based trust on the other hand is defined as the reciprocal emotional ties, concern and care between two people (trustor) and (trustee), which push the former to do something for the latter because it is perceived as amoral duty; affective based trust emphasizes the emotional bonds that exist among employees in an organization (Wilson, Strausb\&McEvily, 2006). Affective based trust emanates from the heart; it is a trust that arises based on one's sense of other's feeling and motives (Chhetri, 2014). This implies that affective based trust exist between two people or groups when one person or group (trustor) feels that the trustee has intentions of doing good (Chhetri, 2014).These two dimensions of interpersonal trust complement each other because for a strong working relationship to exist among workers, cognitive based trust has to be developed and this in turn gives birth to emotional attachment (affective based trust) towards a fellow worker (McAllister, 1995).

\subsection{Measures of Workplace Deviant Behaviour}

A study conducted by Robinson and Bennett (1995) observed that deviance vary along a trend of negativity from minor forms of deviance to a more serious form. However, two measures of deviance were identified by Robinson and Bennett (1997) to include minor versus serious and inter-personal versus organizational deviance. The study also brought about the development of a typology of deviant behaviour which was designed to capture these dimensions and the four quadrants of deviance.

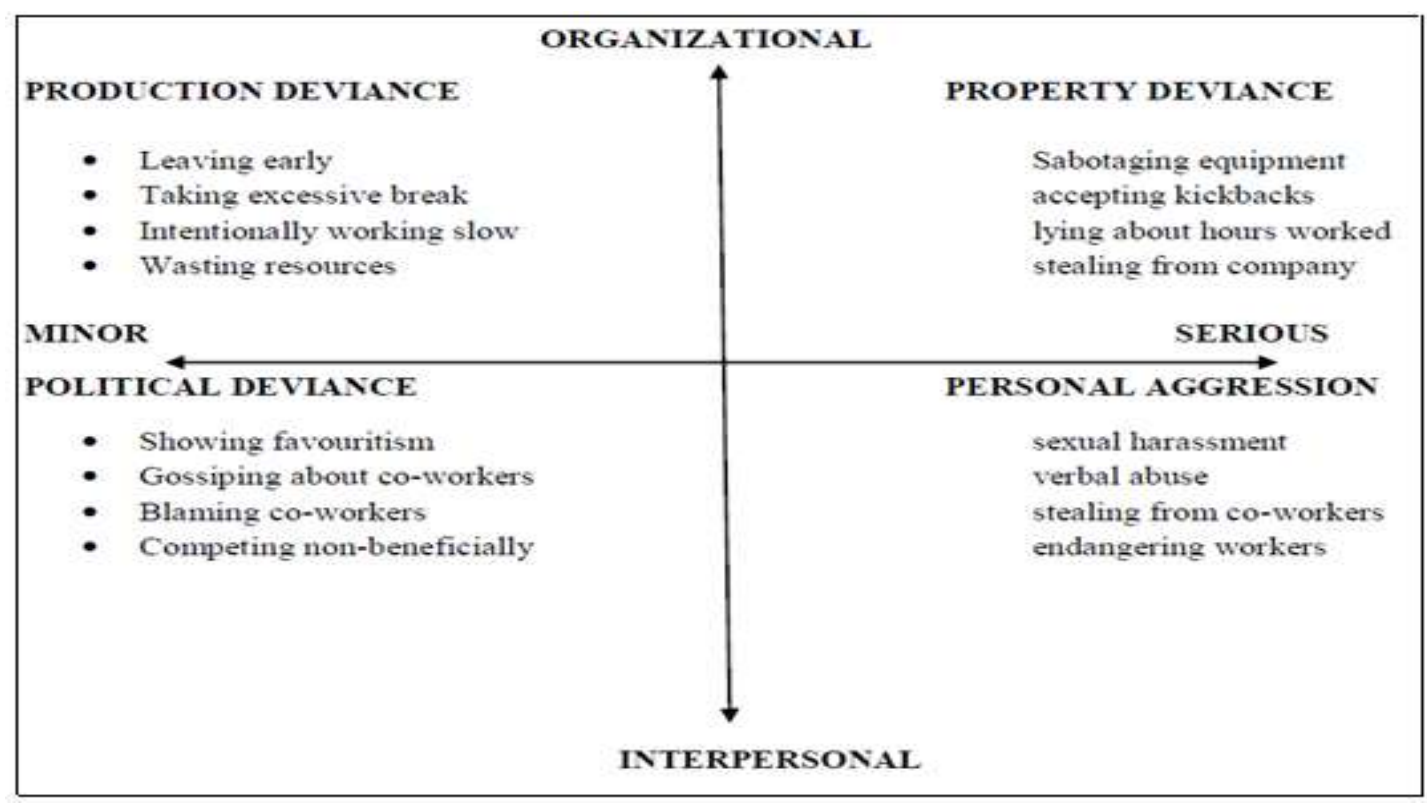

Source: Robinson \& Bennett (1995). TYPOLOGY OF NEGATIVE WORKPLACE DEVIANCE

Source: ( Robinson\&Bennet, 1995). 


\subsection{Adopted from Robinson \& Bennet, 1995}

Organizational Deviance: this refers to negative behaviours by individuals which are directed towards the organization. Such behaviours include sabotage, lateness or putting little effort to work, taking excessive breaks etcetera (Robinson \& Bennett, 1995).

Interpersonal Deviance on the other hand refers to the negative behaviours which are displayed between two or more individuals in the workplace. Such behaviours are gossiping, blaming coworkers and showing favoritism which ranges from minor to more serious behaviours like harassing a co- worker sexually, verbal abuse, stealing from co-workers among others. (Robinson \& Bennett, 1995).

However, the two dimensions of workplace deviance yielded as a result of Robinson and Bennett's (1995) study was further divided into four quadrants to include production deviance, property deviance, political deviance and personal aggression. Furthermore, production and property deviance were further classified under organizational deviance while political and personal aggression are grouped under inter-personal deviance because the behaviours under them are directed at the organization while the behaviours under political deviance and personal aggression are directed at a co-worker in the organization.

\section{Methodology}

The study adopted a cross sectional survey. The population of study constituted 175 respondents (Heads of Departments) who were drawn from six higher institutions in Rivers state, Nigeria. Simple random sampling technique was adopted for the research because it gives each element an equal chance of being selected. Using Taro Yamene's formula, a minimum sample size of 122 was derived hence, the sample size for each institution was estimated using Bowley's proportional allocation technique which is given as $\mathrm{nh}=\mathrm{nNh} / \mathrm{N}$. where $\mathrm{nh}=$ number of units allocated to each sub group (that is each institution used in the study), $\mathrm{Nh}=$ number of respondents in each institution, $\mathrm{n}=$ sample size and $\mathrm{N}=$ total population. Thus, the number of questionnaire given to each institution was $53,18,13$, 11,19 and 8 respectively. Questionnaire was used for data generation and the questionnaire applied a five points likert scale format which are strongly agree ( 5 point), Agree (4 point), Neutral ( 3 point), Disagree (2 point) and strongly Disagree (1 point). However, other scholars work related to the study were extensively reviewed. The research hypotheses were tested using Spearman's rank order correlation coefficient determined through the use of Statistical Package for Social Sciences (SPSS).

\section{Results}

A total of 122 copies of the structured questionnaire were personally distributed by the researcher to the higher institutions under study and 114 copies of the questionnaire were retrieved and in usable form representing $93 \%$ response rate.

The returned copies of the questionnaire were properly checked to ensure that it was properly filled. They were thoroughly edited to see that errors detected were effectively corrected.

\subsection{Hypothesis one}

8.1.1. Spearman's rank correlation of impersonal trust and organizational deviance

\begin{tabular}{|c|c|c|c|c|}
\hline \multicolumn{5}{|c|}{ Correlations } \\
\hline & & & Impersonal Trust & $\begin{array}{l}\text { Organizational } \\
\text { Deviance }\end{array}$ \\
\hline \multirow{6}{*}{ Spearman's rho } & \multirow{3}{*}{ Impersonal Trust } & Correlation Coefficient & 1.000 & $-.626^{* * *}$ \\
\hline & & Sig. (2-tailed) & 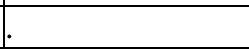 & .003 \\
\hline & & $\mathrm{N}$ & 114 & 114 \\
\hline & \multirow{3}{*}{ Organizational Deviance } & Correlation Coefficient & $-.626^{* *}$ & 1.000 \\
\hline & & Sig. (2-tailed) & .003 & $\sigma^{\circ}$ \\
\hline & & $\mathrm{N}$ & 114 & 114 \\
\hline
\end{tabular}

**. Correlation is significant at the 0.01 level (2-tailed). 
The above correlation reveals that there exist a significant negative relationship between impersonal trust and organizational deviance. The rho shows a negative value of -0.626 at a significant value of 0.003 . Since it is less than the acceptable value of significance $(0.05)$, it shows that there is a significant relationship between impersonal trust and organizational deviance. Therefore, the null hypothesis is rejected while the alternate is accepted.

\subsection{Hypothesis one}

8.2.1. Spearman's rank correlation of impersonal trust and interpersonal deviance

\begin{tabular}{|c|c|c|c|c|}
\hline \multicolumn{5}{|c|}{ Correlations } \\
\hline & & & $\begin{array}{c}\text { Impersonal } \\
\text { Trust }\end{array}$ & $\begin{array}{c}\text { Interpersonal } \\
\text { Deviance }\end{array}$ \\
\hline \multirow{6}{*}{ Spearman's rho } & \multirow{3}{*}{ Impersonal Trust } & Correlation Coefficient & 1.000 & $-.738^{* *}$ \\
\hline & & Sig. (2-tailed) & . & .000 \\
\hline & & $\mathrm{N}$ & 114 & 114 \\
\hline & \multirow{3}{*}{ Interpersonal Deviance } & Correlation Coefficient & $-.738^{* * *}$ & 1.000 \\
\hline & & Sig. (2-tailed) & .000 & \\
\hline & & $\mathrm{N}$ & 114 & 114 \\
\hline
\end{tabular}

The above correlation reveals that there exist a significant negative relationship between impersonal trust and interpersonal deviance. The rho shows a negative value of -0.738 at a significant value of 0.000 . Since 0.000 is less than the acceptable value of significance (0.05), it shows that there is a significant relationship between impersonal trust and interpersonal deviance. Therefore, the null hypothesis is rejected while the alternate is accepted.

\subsection{Hypothesis Three}

\subsubsection{Spearman's rank correlation of interpersonal trust and organizational deviance}

\begin{tabular}{|c|c|c|c|c|}
\hline \multicolumn{5}{|c|}{ Correlations } \\
\hline & & & Interpersonal Trust & $\begin{array}{l}\text { Organizational } \\
\text { Deviance }\end{array}$ \\
\hline \multirow{6}{*}{ Spearman's rho } & \multirow{3}{*}{ Interpersonal Trust } & Correlation Coefficient & 1.000 & $-.584^{* *}$ \\
\hline & & Sig. (2-tailed) & $a^{\circ}$ & .007 \\
\hline & & $\mathrm{N}$ & 114 & 114 \\
\hline & \multirow{3}{*}{ Organizational Deviance } & Correlation Coefficient & $-.584^{* * *}$ & 1.000 \\
\hline & & Sig. (2-tailed) & .007 & \\
\hline & & $\mathrm{N}$ & 114 & 114 \\
\hline
\end{tabular}

The above table with $\mathrm{rh} 0=-0.584, \mathrm{P}=0.007 \leq 0.05$ indicates that there is a significant negative relationship between interpersonal trust and organizational deviance since the p-value is less than 0.05 . Therefore, we reject the null hypothesis and accept the alternate.

\subsection{Hypothesis Four}

\subsubsection{Spearman's rank correlation of interpersonal trust and interpersonal deviance}

\begin{tabular}{|c|c|c|c|c|}
\hline \multicolumn{5}{|c|}{ Correlations } \\
\hline & & & $\begin{array}{l}\text { Interpersonal } \\
\text { Trust }\end{array}$ & $\begin{array}{l}\text { Interpersonal } \\
\text { Deviance }\end{array}$ \\
\hline \multirow{6}{*}{ Spearman's rho } & \multirow{3}{*}{ Interpersonal Trust } & Correlation Coefficient & 1.000 & $-.634^{* * *}$ \\
\hline & & Sig. (2-tailed) & & .003 \\
\hline & & $\mathrm{N}$ & 114 & 114 \\
\hline & \multirow{3}{*}{ Interpersonal Deviance } & Correlation Coefficient & $-.634^{* *}$ & 1.000 \\
\hline & & Sig. (2-tailed) & .003 & \\
\hline & & $\mathrm{N}$ & 114 & 114 \\
\hline
\end{tabular}

The above correlation with ( $\mathrm{rh} 0=-0.634, \mathrm{P}=0.003 \leq 0.05$ ) indicates that there is a significant negative relationship between interpersonal trust and interpersonal deviance since the p-value is less than 0.05. Therefore, we reject the null hypothesis and accept the alternate. 


\subsection{Summary of Hypotheses Testing Result}

\begin{tabular}{|c|c|c|c|}
\hline $\mathbf{S} / \mathbf{N}$ & Hypotheses & Result & Decision \\
\hline $\mathrm{HO}_{1}$ & $\begin{array}{l}\text { There is no significant relationship between } \\
\text { impersonal trust and organizational deviance in } \\
\text { higher institutions in Rivers state. }\end{array}$ & $\begin{array}{l}\text { rho }=-0.626 \\
\text { p-value }=0.003\end{array}$ & $\begin{array}{l}\text { Reject } \mathrm{H}_{1} \text { since } \mathrm{p} \text {-value } \\
<0.005 \text { significance level. }\end{array}$ \\
\hline $\mathrm{HO}_{2}$ & $\begin{array}{l}\text { There is no significant relationship between } \\
\text { impersonal trust and interpersonal deviance in } \\
\text { higher institutions in Rivers state. }\end{array}$ & $\begin{array}{l}\text { rho }=-0.738 \\
\text { p-value }=0,000\end{array}$ & $\begin{array}{l}\text { Reject } \mathrm{HO}_{2} \text { since } \mathrm{p} \text {-value } \\
<0.005 \text { significance level. }\end{array}$ \\
\hline $\mathrm{HO}_{3}$. & $\begin{array}{l}\text { There is no significant relationship between } \\
\text { interpersonal trust and organizational deviance } \\
\text { in higher institutions in Rivers state. }\end{array}$ & $\begin{array}{l}\text { rho }=-0.584 \\
\text { p-value }=0.007\end{array}$ & $\begin{array}{l}\text { Reject } \mathrm{H}_{3} \text { since } \mathrm{p} \text {-value } \\
<0.005 \text { significance level. }\end{array}$ \\
\hline $\mathrm{HO}_{4}$. & $\begin{array}{l}\text { There is no significant relationship between } \\
\text { interpersonal trust and interpersonal deviance } \\
\text { in higher institutions in Rivers state. }\end{array}$ & $\begin{array}{l}\text { rho }=-0.634 \\
\text { p-value }=0.003\end{array}$ & $\begin{array}{l}\text { Reject } \mathrm{H}_{4} \text { since } \mathrm{p} \text {-value } \\
<0.005 \text { significance level. }\end{array}$ \\
\hline
\end{tabular}

\section{DISCUSSION OF FINDINGS}

This research was carried out with the aim of examining the relationship between organizational trust and workplace deviant behaviour. The results of this research work have clearly shown that there is a significant but negative relationship between organizational trust and workplace deviant behaviour. It also revealed a correlation between all dimensions of organizational trust and workplace deviant behaviour.

\section{HYPOTHESIS ONE DISCUSSION OF FINDINGS}

The result of the test of hypothesis one revealed a negative significant relationship between impersonal trust and organizational deviance in higher institutions in Rivers state. This was shown by correlation coefficient of $(r)=-0.626)$. Moreso, the coefficient of determination $\left(r^{2}\right)$ is $(0.391)$ indicating that $39 \%$ of organizational deviance can be influenced by impersonal trust. This implies that when impersonal trust increases in higher institutions, organizational deviance reduces. In essence, when there is a reliable structure, a concrete vision and strategy in an organization, destructive and harmful behaviour by employees towards the organization will reduce and vice versa. This is in line with the work of Baghani, Pourkiani and Abbasi (2014) which postulates that when organizational trust is high, organizational deviant behaviour of employees decrease.

\section{Hypothesis TWO Discussion OF Findings}

The result of hypothesis two revealed a negative significant relationship between impersonal trust and interpersonal deviance in higher institutions in Rivers state. This was shown by correlation coefficient of $(r)=-0.738)$. Moreso, the coefficient of determination $\left(r^{2}\right)$ is $(0.544)$ indicating that $54 \%$ of interpersonal deviance can be influenced by impersonal trust. This means when employees realize that the organization is capable of settling their salary and other entitlement as at when due, the chances of trespassing with a fellow worker's property will be reduced. This correspond with the study conducted by Fagbohungbe, Akinbode and Ayodeji (2012) which revealed that when organization's reaction towards employees is good, the employees will hardly exhibit deviant behaviours in the workplace.

\section{HYPOTHESIS THREE DISCUSSION OF FINDINGS}

The result of hypothesis three indicated a negative significant relationship between interpersonal trust and organizational deviance in higher institutions in Rivers state. This was shown by correlation coefficient of $(r)=-0.584)$. Moreso, the coefficient of determination $\left(r^{2}\right)$ is $(0.341)$ indicating that $34 \%$ of organizational deviance can be influenced by interpersonal trust. Signifying that unity among workers reduces their degree of breaching the significant norms and values of the organization. The results of this study support the work of Aslani, Soraya and Zavari (2014) which revealed that when organization's reaction towards employees is good, the employees will hardly exhibit deviant behaviours.

\section{HYPOTHESIS FOUR DISCUSSION OF FINDINGS}

The result of hypothesis four revealed a negative significant relation relationship between interpersonal trust and interpersonal deviance in higher institutions in Rivers state. This was shown by correlation coefficient of $(r)=-0.634)$. Moreso, the coefficient of determination $\left(r^{2}\right)$ is $(0.401)$ 
indicating that $40 \%$ of interpersonal deviance can be influenced by interpersonal trust. This supports the work of Baghani, Pourkiani and Abbasi (2014) which the result of their study showed a significant reverse relationship between tendency to trust in the workplace and interpersonal deviant. Implying that tendency to trust fellow worker in the workplace reduces interpersonal deviant behaviour and vice versa.

\section{CONCLUSION}

Based on the findings of the study, the following conclusion was made.

Impersonal trust which entails employee's trust in organization's vision and structure, the belief that proper impersonal structure has been put in place to enable employees to anticipate a successful future, significantly influence organizational deviance in higher institutions in Rivers state.

An increase in impersonal trust reduces interpersonal deviance and vice versa among employees of higher institutions in Rivers state.

Interpersonal trust which is the degree to which people ascribe good intentions and abilities to peer in the workplace is significantly related to organizational deviance. Interpersonal trust though related to interpersonal deviance, has a negative relationship, such that as one variable increases, the other reduces.

\section{RECOMMENDATIONS}

Arising from the discussion of findings, the following were recommended. Hence, these recommendations are linked to the four hypotheses respectively.

1. Management of higher institutions should have reliable impersonal structures that guarantee the employees a successful future, assure them of job security thereby reducing and or eradicating workplace deviant behaviours in higher institutions.

2. Management should strive and meet the basic needs of their employees in order to make them have a work-life balance (working and having their lives protected). By so doing, interpersonal deviance will be reduced.

3. Management should encourage team work among employees to boost their level of interpersonal trust. Incentives should be given to hard working staff as this will motivate others to work hard towards achieving success other than causing harm to the organization.

4. Management should frequently carryout programs such as symposia, conference, workshop etcetera to educate the employees on the importance of honesty, reliability and accountability among workers as this will inspire the best among their workers an hence, reducing interpersonal deviance.

\section{CONTRIBUTION TO KNOWLEDGE}

- This study has bridge the gap in the existing body of literature on organizational trust and work place deviant behaviour by particularly examining the relationship between organizational trust and workplace deviant behaviour in higher institutions in Rivers state.

- This research work has revealed the various deviant behaviours exhibited by employees in the workplace, the causes and possible ways of reducing or eradicating such deviant behaviours in order to achieve effective performance.

- The work will serve as handy material to students and scholars in the field of human resource management. The study will also help managers in the formulation of policies regarding organizational trust and workplace deviant behaviour.

\section{REFERENCES}

[1] Anwar, M.N., Sarwar, M., Awan, R.N. \& Arif, M.I. (2011).Gender Differences in workplace deviant behaviour of University Teachers and modification techniques. International Education studies 4(1), 1319.

[2] Appelbaum, S.H., Iaconia, G.D. \& Matousek (2007). Positive and negative deviant workplace behaviour: causes, impact and solutions, corporate Governance, 7(5), 586-598. 
[3] Arslan, M.M. (2009). Organizational trust perception of teachers of technical and industrial vocational High school. Journal of methods and practice in Education, 5(2), 274-288.

[4] Aslani, F., Soraya, P. \& Zavari, M. (2014). Organizational Trust and Deviance Behaviour. ( A case of Payame Noor University of Isfahan Province, Iran. Journal of Economics and Management 3(3), 122-127.

[5] Atkinson, S. \& Butcher, D. (2003). Trust in managerial relationships. Journal of managerial psychology, 18(4), 282-304.

[6] Baghini, B.Z., Pourkiani, M. \&Abbasi, F.B.(2014). The Relationship between Organizational Trust and Organizational Deviant Behaviour of Staff in Rafaah bank branches in Kerman City. Arabian Journal of Business And Management Review. 3(11), 124-133.

[7] Bakiev, E. (2013). The influence of interpersonal trust and organizational commitment on perceived organizational performance.Journal of Applied Economics and Business Research, 3(.3), 166-180.

[8] Bennett, R. \& Robinson, S. (2000). Development of a measure of workplace Deviance. Journal of Applied Psychology, Vol.85, N0.3,pp.349-360.

[9] Bennett, R. \& Robinson, S. (2003). "The past, present and future of workplace deviance research" in Greenberg, J. (ed.), organizational Behaviour. The state of the science, $2^{\text {nd }}$ ed; Erlbaum, Mahwah, NJ.

[10] Bennett, R. \& Stamper, C. (2001). Corporate citizenship and deviancy in organization: A study of discretionary work behaviour. International research in the business disciplines, 3(1), 265-284.

[11] Bilgiç, Ö. (2011). Perception of primary school teachers related with organizational trust levels. Unpublished M.sc thesis, Yildiz Teknik university, Graduate school of social sciences, Istanbul.

[12] Çelik, M., Turunç, O. \& Bergenirbas, M. (2011).The role of organizational trust, burnout and interpersonal deviance for achieving organizational performance .International Journal of Business and management studies, 3(2), 179-189.

[13] Chang, K. \& Smithikrai, C. (2012). Counter- productive behaviour at work: An investigation into reduction strategies, the International Journal of Human Resource Management, 21(8), 1272-1288.

[14] Chhetri, P. (2014). The role of cognitive and affective trust in the relationship between organizational justice and organization citizenship behaviour: A conceptual Framework. Journal of Business theory and practices. $15(2), 170-178$.

[15] Chikwature, W. \&Oyedele, V. (2016).Effects of Deviant behaviour on Academic performance in Mature Urban primary schools in Mature District. European Journal of Psychology Research. 3(1), 35-45.

[16] Chowdhury, S. (2005). The role of affect and cognitions-based trust in complex knowledge sharing. Journal of managerial issues 17(3), 310-326.

[17] Colquitt, J.A, Scott, B.A. \& Lepine, J.A. (2007). Trust, trustworthiness and trust propensity: A metaanalytic test of their unique relationships with risk taking and job performance. The Journal of Applied psychology, 94(4), 909-927. http//dx.doi.org/10.1037/0021-9010.92.4.909.

[18] Dasguspa, P. (1988). Trust as a commodity in Trust making and Breaking cooperative Relations, Diego Gambetta and Basil Blackwell ed: NewYork.

[19] Demircan, N. Ceylan, A. (2003). The concept of Organizational Trust: Reasons and Results. Journal Of management and Economy 10(2), 139-150.

[20] Dursun, E. (2015). The relationship between Organizational Trust, Organizational support and Organizational Commitment. African Journal of Business Management. 9(4), 134-156. Doi: 10.5897/AJBM2014.7623.

[21] Ellonen, R., Blomqvist, K. \& Puumalainen, K. (2008).The role of trust in organizational innovativeness. European Journal of innovation management, 11(2), 160-181.

[22] Erat, S., ErdiI, O. Kitapçi, H. \& Çömlek, O. (2012). The effect of the perception of organizational trust and organizational support on intention to quit and individual performance: An empirical study of the Turkish State universities. African Journal of Business management, 6(30), 8853-8861.

[23] Espein, S. (2003).Cognitive- Experimental Self Theory of Personality. Comprehensive Handbook of Psychology. 5(1), 159.184.

[24] Fagbohungbe, B. Akinbode, G. \&Ayodeji, F. (2012). Organizational determinants of workplace deviant behaviour: An empirical analysis in Nigeria, International Journal of Business and Management, 7(5), 207-221.

[25] Galperin, B. L. \& Burke, R.J. (2006).Uncovering the relationship between work aholism and workplace destructive and constructive deviance. An Exploratory study. The International journal of Human Resource Management. 17(4), 331-347. Doi: 10.1080/09585190500404853. 
[26] Galperin, B. L. (2012). Exploring the nomological network of workplace deviance: Developing and validating a measure of constructive deviance. Journal of Applied social psychology, 42(8), 2988-3025. Http// doi:10.1111/j.1559-1816.2012.00971.

[27] Galperin, B.L. (2002). Determinants of deviance in the workplace: an empirical examination in Canada and Mexico. Unpublished Ph.D Thesis, Concordia University.

[28] Geller, E. (1999).Behaviour-based safety: Confusion, Controversy and Clarification. Journal of Occupational Health \& Safety. 68(1), 40-50.

[29] Gibbs, J. (1972). TORI Theory and Practice. In J.W. Pfieffer and J. Jones (eds). The Annual Handbook for Group Facilitators, San Francisco, CA: Pfieffer/ Jossey-Bass.

[30] Gilbert, J.A., \& Tang, T.L (1998).An examination of Organizational trust antecedents.Public personnel Management Journal, 27(1), 321-338.

[31] Greenberg, J. (1997). “Managing the social determinants of employee theft”.In Giacalone, R. \& Greenberg. J. (Eds.), Antisocial Behaviour in Organizations. London, Uk: Sage Publications, Inc.

[32] Gülsüm, B., Adem, P., Mehmet, K.,IIker, G. \& Mehdi, D. (2016). Investigation of the relationship between organizational trust and organizational commitment, Universal journal of Educational Research, 4(6), 1418-1425.

[33] Hassan, M. \& Sermerciöz, F. (2010). Trust in personal and interpersonal forms, its antecedents and consequences: A conceptual analysis within organizational context. International journal of management and information systems, 4(6), 67-84.

[34] Joe-Akunne, C.O., Oguegbe, T.M., \& Okonkwo, K.I. (2015). Impact of Emotional Intelligence and job Boredom proness on counter productive work behavior American Institute of Science, 1(2), 101-106.

[35] Johnson, D. \& Grayson, K. (2005). Cognitive and affective based trust in service relationships. Journal of business Research,58(6), 500-507.

[36] Kabiru, K., Faradahwati, S. \&Chauhan, A. (2013). Influence of organizational format control on workplace deviance: A pilot study, Middle -East Journal of Scientific Research, 13(4), 538-544, Dio:5829/idosi.mejsr.2013.13.4.312.

[37] Lazaric, N. (2003). Trust building inside the Epsitemic community: An investigation with an empirical case study, E. Elgar publishing, USA.

[38] Liden, R.C., Wayan, S.J., Zhoa, H., \& Henderson, D. (2005).Development of multidimensional measure of servant leadership, Management Association, Charleston, SC.

[39] Mathew, O.T., Chigozie, U. B. \&Kosiso A. (2014). Workplace Deviance: A Predictive study of occupational stress and emotional Intelligence among secondary school teachers. International Journal of Academic Research in Business and social sciences. 4(12), 178-186. Doi.10.6007/IJARBSS/v4-i12/1337.

[40] Mayer, R. Davis, J. \& Schoorman. F. (1995).An Integrative Model of Organizational Trust. Academy of Management Review. 20(3), 709-734.

[41] McAllister, D. (1995). Affect and Cognitive-Based Trust as Foundations for Interpersonal Cooperation in organizations.The Academy of Management Journal, 38(1), 24-59.

[42] McCauley, D. \& Kuhnert, K. (1992). A theoretical review and empirical investigation of employee trust in management. Journal of Public Administration, 16(2), 265-285.

[43] McDonough, J. (2009). Handbook of Biological Statistics (2 ${ }^{\text {nd }}$ ed.). Baltimore: MD Sparky House Publishing.

[44] McKnight, D. Cummings, L. \& Chervany, N. (2008). Initial Trust Formation in New Organizational Relationships. Academy of Management Review, 23(3), 473-490.

[45] Merrel, K.W., Ervin, R.A. \& Gimpel-Peacock, G. (Ed.). (2012). Practical Handbook Of School Psychology: Effective Practices for $21^{\text {st }}$ Century. New York, NY: Guildford press.

[46] Mishra, A.K. (1996). Organizational responses to crisis: the centrality of trust”, in Kramer, R.M and Tyler, T.R (ed.): Trust in organizations: frontiers of Theory and research", 261-287. Thousand Oaks, CA: Sage

[47] Morgan, R.M. \& Hunt, S.D. (1994). The commitment Trust theory of relationship marketing. Journal of marketing, 58(3), 20-39.

[48] Muafi, J. (2011). Causes and consequences of deviant workplace behavior International Management and Technology Journal. 2(2), ppp.123-126.

[49] Murphy, K.R. (1993). Honesty in the work place.Belmont, CA: Brooks/Cole. 
[50] Nwankpa, J. K. \&Roumani, Y. (2014). "Influence of Organizational Mindfulness on Enterprise Resource Planning (ERP) system usage.Communications of the Association for information systems: Vol.34, No. 85, pp.1470-1492.

[51] O’Brien, R. (2001). Trust: Releasing the energy to succeed, Wiley, Chichester.

[52] O’Leary-kelly, A. M., Griffin, R. W., \& Glew, D.J. (1996). Organizational motivated aggression: A research framework. Academy of management Review, 21(4), pp. 225-252.

[53] Omar, F., Halim, F.W., Zainah, A.Z., Farhadi, H., Nasir, R. \&Khairudin, R. (2011). Stress and Job Satisfaction as antecedents of workplace deviance: World Applied Science Journal. 12(9), 46-51.

[54] Omarov, A. (2009). Organizational trust and work satisfaction: An application in private sector, Dokuz Eylül, Graduate school of social sciences, department of Business, Izmir, Unpublished M.sc thesis.

[55] Panahi, B., (2008). Trust and confidence in the organization. Light carrier Journal, 7(4), 88-103.

[56] Rafiee, M., Hoveida, R. \&Rajaeipoor, S. (2015). The relationship of the deviant workplace behaviour with organizational Justice and staff development in the Universities of Tehran, International Journal of Human Resource studies, 5(1), 126-140.

[57] Reina, D. \& Reina, M. (1999). Trust and Betrayal in the workplace: Building effective relationship in your organization, Berrett-Koehler, San Francisco, CA.

[58] Rezaei, M., Salehi, S., Shafiei, M. \&Sabet, S. (2012). Servant Leadership and Organizational trust: The mediating effect of the leader trust and Organizational Communication. Emerging Market Journal, 2(3), 70-78.DOI. 10.5195/emaj.2012.21

[59] Robinson, S., \& Bennett, R. (1995). “A typology of deviant workplace behaviours: A multi- dimensional scaling study". Academy of Management Journal, .38(2), 555-572. Retrieved athttp://dx.doi.org/10.2307/ 256693.

[60] Robinson, S.,\& Bennett, R. (1997). Workplace deviance" Its definition, its Manifestations and its causes. Research on Negotiations in Organizations. 6(1), 3-27.

[61] Rusu, R. \&Babos, A. (2015).Organizational trust between institutional and Interpersonal trust.Buletic specific. 6(2), 40-43.

[62] Samadi, B., Wei, C., Seyfee, S. \&Yusoff, W. (2015).Conceptual model of organizational trust and knowledge sharing behaviour among multi- generational employees.Asian Social Science, 11(9), 32-42. DOI: $10.5539 /$ ass.v11n9p32.

[63] Semerciöz, F., Aldemir, Z. \& Hassan, M. (2011). An Emperical Study on the Role of Interpersonal and Institutional Trust in organizational innovativeness. International Business Research,4(2), 125-136.

[64] Shamir, B. \&Lapidot, Y. (2003). Trust in organizational superiors: Systematic and Collectice Considerations, Journal of Organizational Studies, 24(1), 463-491.

[65] Shaw, R. (1997). Trust in the balance. Jossey-bass publishers, USA.

[66] Spector, P. \& Fox, S. (2002). An Emotion- Centered Model of Voluntary Work Behaviour: Some parallel between Counterproductive work Behaviour. Journal of Human Resource Management. 12(1), $269-292$.

[67] Spreitzer, G. \&Sonenshein, S. (2003). Positive deviance and extra ordinary organizing. Positive Organizational Scholarship 1(1), 207-244.

[68] Spreitzer, G.\& Sonenshein, S. (2004). Towards the construct definition of positive deviance. American Behavioural scientist, 47(6), 826- 847. http//dx.doi.org/10.1177/0002764203260212.

[69] Sunday, A.J. (2013). Workplace Deviant behaviour: A case of Intels Nigeria Limited. Research on Humanities and social science, 3(22), 49-56.

[70] Sztompka, P. (1999). Trust: A Sociological theory. NewYork: Cambridge University Press.

[71] Vadera, A. Pratt, M. \& Mishra, P. (2013).Constructive deviance in organizations integrating and moving forward. Journal of management, 11(1), 1-56. http://dx.doi.org/10.1177/0149206313475816.

[72] Vardi, Y., \&Wiener, Y. (1996).Misbehaviour in organizations: A motivational framework. Organization Science, 7(1), 151-165. http://dx.doi.org/10.1287/orsc.7.2.151

[73] Warren, D. (2003). Constructive and Destructive Deviance in Organization .Academy of management journal 28(4), 622-632. http://dx.doi.org/10.5465/AMR.2003.10899440.

[74] Webster, J. \& Wong, W.K. (2008). Comparing traditional and virtual group forms: Identity, communication and trust in naturally occurring project teams. The international journal of human resource management, 19(1), 41-62.http://dx.doi.org/10.1080/09585190701763883.

[75] Wilson, J., Strausb, S. \&McEvily, B. (2006). All in due time; The development of trust in computedmediated and face to face teams. Organizational Behaviour and Human Decision process, 99(1), 16-33. Doi:10.1016/j.obhdp.2005.08.001. 
[76] Yeliz, S. (2016).Organizational Justice. Organizational trust and organizational Identification perceptions of physical Education Teachers. International Journal of business and Social science, 7(2), 126-133.

[77] Yildiz, B., Alpkan, L., Ateş, H. \&Sezen, B. (2015). Determinants of constructive deviance: The mediator role of psychological ownership. International Business Research, 8(4) 107-121.

[78] Zhu, W., Newman, A., Miao, Q. \&Hooke,A. (2013). The Leadership Quarterly, 24(1), 94-105.

Citation: Dr Omoankhanlen Joseph, Akhigbe, and Sunday Philip Imefon. "Organizational Trust and Workplace Deviant Behaviour in Higher Institutions in Rivers State." International Journal of Managerial Studies and Research (IJMSR), vol 5, no. 10, 2017, pp. 48-62. doi:http://dx.doi.org/10.20431/23490349.0510005.

Copyright: (C) 2017 Authors. This is an open-access article distributed under the terms of the Creative Commons Attribution License, which permits unrestricted use, distribution, and reproduction in any medium, provided the original author and source are credited. 